\title{
CHARACTERISTICS OF EGG WHITE EFFERVESCENT TABLET WITH DIFFERENT EFFERVESCENT MIX CONCENTRATION
}

\author{
Zakiah Wulandari $^{* 1)}$, D.R. Pamungkas ${ }^{2) .}$ H. Hamasyah ${ }^{2)}$ B. N. Polii ${ }^{3)}$ \\ 1) Departemen Ilmu Produksi dan Teknologi Peternakan FAPET IPB, Jalan Agatis Kampus IPB, Babakan, \\ Dramaga, Babakan, Kec. Dramaga, Bogor, Jawa Barat, Indonesia, 16680 \\ 2) Alumni Departemen Ilmu Produksi dan Teknologi Peternakan FAPET IPB, Jalan Agatis Kampus IPB, \\ Babakan, Dramaga, Babakan, Kec. Dramaga, Bogor, Jawa Barat, Indonesia, 16680 \\ ${ }^{3)}$ Pensiunan Departemen Ilmu Produksi dan Teknologi Peternakan FAPET IPB, Jalan Agatis Kampus IPB, \\ Babakan, Dramaga, Babakan, Kec. Dramaga, Bogor, Jawa Barat, Indonesia, 16680 \\ Email: zakiahwulandari75@gmail.com
}

Submitted 26 July 2020; Accepted 30 November 2020

\begin{abstract}
Egg white is one source of protein that has many functions, including as an antimicrobial, antihypertensive, anti-cancer, and this can also be used as a preservative and sweetener. The addition of egg white powder to effervescent tablets with lemon essence is expected to increase protein levels in the tablet. The purpose of this study was to study the physical, chemical and organoleptic characteristics of effervescent tablets by adding egg white powder to the formulation. The study design used a randomized block design (RBD) with the making period as a group. The treatments used were different concentrations of effervescent mix (sodium bicarbonate, citric acid and tartaric acid), that is, 55, 60 and 65\%. Data from the test results were tested with analysis of variance (ANOVA), further tests with the Duncan test. The physical characteristics of effervescent tablets with the addition of egg white powder and the difference in the concentration of effervescent mix as a treatment were not significantly different among treatments. The chemical characteristics of egg white effervescent tablets did not change with the treatment concentration of effervescent mix 55, 60 and $65 \%$ but the water activity (aw) of the effervescent tablets changed. Increasing the concentration of effervescent mix treatment can reduce the value of aw from 0.58 to 0.50 . The addition of albumen powder with different concentrations of effervescent mix resulted in effervescent tablets according to predetermined standards. The organoleptic test results on the overall assessment of egg white powder effervescent tablets were somewhat favorable
\end{abstract}

Keywords: Albumen powder; effervescent tablet; maltodextrin; protein; spray dryer 


\section{INTRODUCTION}

Eggs are food resulted from livestock that have high nutritional value, especially protein. This tasty, easily digestable and highly nutritious food can be easily obtained, and the price is quite cheap. Its egg white is the part of an egg that is known as a source of protein. The protein concentration of egg white is $11 \%$. The protein of egg white is composed of several types of protein, namely: ovalbumin, ovomucoid, ovomucin, ovoglobulin, ovotransferin, ovoinhibitor, avidin and lysozyme. Some proteins of egg white contain many bioactive components. These bioactive components can function as antimicrobial, antihypertensive, anti-cancer and they can also be used as preservatives and sweeteners (Stadelman and Cotterill, 1995; Nimalaratne and $\mathrm{Wu}, 2015$; Asoodeh et. Al., 2011; Wulandari, 2019).

Effervescent drink is one of favorite drinks by the community. Egg white supplementation in effervescent drinks is expected to increase consumer acceptance and increase protein consumption. Instant drinks that take advantage of the effervescent effect are instant drinks that will give an attractive impression because of their distinctive sparkling effect and taste. Effervescent drink tablets or powders also do not require a stirrer because the effervescent effect can dissolve the drink ingredients by itself, so it has a higher practical value. This effervescent reaction is desired to occur spontaneously when the effervescent is dissolved in water.

Lemon flavored essence has been frequently used as a flavor enhancer in the beverage industry. Its distinctive and refreshing aroma and taste are the main attraction for consumers. The use of lemon- flavored essence and effervescent effect in egg white effervescent tablet products is expected to increase acceptance of this type of drink in the community.

This research aimed to study the physical, chemical and organoleptic characteristics of effervescent tablets with the addition of egg white to the formulation.

\section{MATERIALS AND METHODS}

The ingredients used were egg white, maltodextrin, $\mathrm{K}_{2} \mathrm{SO}_{4}, \quad \mathrm{HgO}, \quad \mathrm{H}_{3} \mathrm{PO}_{3}$, concentrated $\mathrm{NaOH}$, lanthanum chloride, Whatman No 541 filter paper, 91-92\% concentrated $\mathrm{H}_{2} \mathrm{SO}_{4}$, phenolptalein indicator, $\mathrm{pH} 4$ and 7 buffer, aquadest, polyvinylpyrrolidone (PVP). ), polyetylene glycol (PEG 6000), citric acid, tartaric acid, sodium bicarbonate, acesulfam, lactose, 96\% ethanol, lemon-flavored essence (lemon encapsulates, Keith Harris), tartrazine (dye).

The device used to make egg white powder is a spray dryer from the Buche brand type B-190. The device for making effervescent tablets consists of oven type 11.15, moisture balance ohaus MB 2000, sieve (11 mesh), and analytical balance with an accuracy of $0.001 \mathrm{~g}$, desiccator, tablet printing machine. The tools used for the analysis consist of a Kjeldahl flask, Erlenmeyer flask, porcelain cup, distillation tube, water bath, type 11.5 oven, desiccator, analytical balance with an accuracy of 0.0001g (Precisa 220A, Switzerland), furnace, $\mathrm{pH}$ meter (Hanna, USA), AAS Agilent Technologies 200 series AA flame type atomic absorption spectrophotometer (AAS), 100x165 (500 g-0.01 g) notebook analytic scales. The research is divided into two stages, namely the first stage research and the second stage research.
*Corresponding author:

Zakiah Wulandari

Email: zakiahwulandari75@gmail.com

Departemen Ilmu Produksi dan Teknologi Peternakan FAPET IPB, Jalan Agatis Kampus IPB, Babakan, Dramaga, Babakan, Kec. Dramaga, Bogor, Jawa Barat, Indonesia, 16680
How to cite:

Wulandari, Z., Pamungkas, D. R., Hamansyah, H., \& Polii, B. N. (2021). Characteristics of egg white effervescent tablet with different effervescent mix concentration. Jurnal Ilmu dan Teknologi Hasil Ternak (JITEK), 16 (1), 54-64 


\section{First Stage Research}

The aim of this research was to find the best solubility of egg white powder with the addition of maltodextrin as a filler. The stages of making egg white powder are as follows: (1) pasteurized egg whites. The process of making egg white powder includes the following: eg gwhites that had been separated from the yolk were then pasteurized using a water bath at $57^{\circ} \mathrm{C}$ for \pm 5 min.

The egg white was then cooled at room temperature, and next this was added with $0.3 \%$ fermipan by weight of the initial egg white, homogenized and after that this was fermented for $3 \mathrm{~h}$. The fermented egg white were added with maltodextrin 5, 10, 15 and $20 \%$ by weight of the initial egg white, then homogenized and dried using a spray dryer with an inlet temperature of $180^{\circ} \mathrm{C}$ and an outlet temperature of $110{ }^{\circ} \mathrm{C}$. The $80 \%$ solubility results would be used to make effervescent tablets in the second phase of research.

\section{Second phase research}

The method used for effervescent tablets was wet granulation. The inner phase material consisted of PVP, $\mathrm{NaHCO}_{3}$ and lactose which have been dissolved with $96 \%$ ethanol. The results of the inner phase were sieved with an 11 mesh sieve and dried in an oven $50-60^{\circ} \mathrm{C}$ for $15 \mathrm{~min}$. The outer phase material consisted of egg white powder, citric acid, tartric acid, acesulfam, PEG 6000 , lemon flavored essence, and then tartrazine was mixed and sieved and then put into the inner phase mixture, homegensized and then printed. The process of making effervescent tablets used the wet granulation method with different concentrations of effervescent mix (sodium bicarbonate, tartric acid, citric acid), namely 55\%, 60\% and $65 \%$.

Table 1. The formulation of main research

\begin{tabular}{lccc}
\hline Material & F1 & F2 & F3 \\
\hline PVP & $\ldots \ldots \ldots \ldots \ldots \ldots \ldots \ldots \ldots \ldots \ldots \ldots \ldots \ldots \ldots \ldots \ldots$ \\
PEG 6000 & 2 & 2 & 2 \\
Acesulfam & 5 & 5 & 5 \\
Lemon flavored essence & 1 & 1 & 1 \\
Tartrazine & 5 & 5 & 5 \\
Lactose & 0.2 & 0.2 & 0.2 \\
Egg white powder & 11.8 & 6.8 & 1.8 \\
Effervescent mix: & 20 & 20 & 20 \\
$\quad$ NaHCO3 & & & \\
$\quad$ Tartric Acid & 26.58 & 29 & 31.42 \\
$\quad$ Citric Acid & 11.46 & 12.5 & 12.64 \\
Total & 16.96 & 18.5 & 20,94 \\
\hline
\end{tabular}

\section{Observed Variables}

The physical variables analyzed were the compressibility test of granules, visual general appearance, weight uniformity, hardness of tablets, friability, tablet size, and dissolving time of tablet (Dep. Kes. RI, 1995). The chemical variables analyzed were $\mathrm{pH}$ value, protein content, ash content, water content, Na mineral content, and water activity (Apriyantono et al., 1989).
The organoleptic variable used was the hedonic test. Panelists gave an assessment of their favorite level of the tablet form, color, aroma, dissolving time, taste and general impression of the tablet product produced. The scale used was up to 7, namely (1) extremely dislike, (2) dislike very much, (3) dislike, (4) quite like, (5) like it, (6) like very much and (7) extremely like. The test used 50 untrained panelists. 


\section{Experimental Design}

A unidirectional randomized block design (RBD) was applied in this study with the group making period. Determination data were tested using analysis of variance (ANOVA), further testing with the Duncan test (Steel and Torrie, 1995). The treatments used were different concentrations of effervescent mix (sodium bicarbonate, citric acid and tartric acid), namely: 55, 60 and $65 \%$.

\section{RESULTS AND DISCUSSIONS}

This first-stage study was conducted to assess the best solubility of egg white powder with the addition of maltodextrin at the time of powdering egg whites, namely $5 \%, 10 \%, 15 \%$ and $20 \%$, respectively. The results of the solubility test of egg white powder after the addition of maltodextrin can be seen in Table 2. Maltodextrin is a soluble starch and it is widely used in the food and pharmaceutical industries (Sansone et al., 2011).
The data in Table 2 shows that the addition of $20 \%$ maltodextrin can increase the solubility of egg white powder compared to other percentages, but the amount of maltodextrin in the egg white powder produced is also higher so that in the main study, egg white powder was used with the addition of $15 \%$ maltodextrin.

The addition of $15 \%$ maltodextrin at the time of the egg white powder can increase the solubility of the egg white powder by $92.42 \%$. Besides that, the determination of the $15 \%$ maltodextrin concentration is to make the resulted egg white powder contain not too much filler. The solubility standard of egg white powder used in this preliminary study is a standard commonly used in pharmaceutical products, namely all ingredients used for the manufacture of effervescent tablets must have high solubility in water and have a fast dissolving time (Lachman et al., 2008). The solubility standard of materials for the manufacture of effervescent tablets is $80 \%$ (APA, 1994).

Table 2. Solubility of egg white powder at various concentrations of maltodextrin

\begin{tabular}{|c|c|}
\hline Maltodextrin Concentration & Egg white powder solubility \\
\hline & \\
\hline 5 & 87.84 \\
\hline 10 & 90.16 \\
\hline 15 & 92.42 \\
\hline 20 & 96.99 \\
\hline
\end{tabular}

The maltodextrin and pectin matrices can also carry polyphenol components by the spray concentration method. The use of maltodextrin and pectin (10: 1) can stably encapsulate $3 \%$ polyphenol-rich extracts and is very easy in storage and handling (Sansone et al., 2011). According to Parikh et al. (2014) maltodextrin is widely used in tablets as a drug entrapment.

The treatments in this main study were different percentages of effervescent mix, namely 55\%, 60\% and 65\%. This different effervescent mix treatment is expected to produce products with the best chemical properties (aw, $\mathrm{pH}$, moisture content, ash content, protein content and $\mathrm{Na}$ content) and also have a good effect on organoleptic properties (color, aroma, taste, foam that is formed and overall assessment).

\section{Compressibility granule}

Granule compressibility is the ability of a granule to be compressed. The influencing factors are the shape, density and size of the granule particles (Lachman, 2008). The compressibility test aimed to determine whether the properties of the material could form a stable and compact mass when given pressure. The smaller the bulk density obtained, the better the flow properties (Aulton, 2002). The treatment results showed that different formulations 
did not have a significant effect $(p>0.05)$ on the compressibility of the granules. This is because the particles of the three formulations are almost the same in size, which differ only in the concentration of the effervescent mix and the concentration of lactose. When the pressure is applied, these two factors do not give a significant difference in the compressibility value of the granules. The average value of the compressibility percentage of egg white effervescent tablet granules was $24.39 \%$. Based on Wells (1987) criteria, the three formulas tested produced egg white effervescent granules that met the compressibility criteria quite well. Good compressibility is indicated by the uniform size and shape of the particles, which makes printing easier and produces a compact egg white effervescent tablet when printed.

Table 3. Average value of physical characteristics of effervescent tablets

\begin{tabular}{lccc}
\hline \multicolumn{1}{c}{ Observed Variables } & $\mathrm{F} 1$ & $\mathrm{~F} 2$ & $\mathrm{~F} 3$ \\
\hline Compressibility of granules $(\%)$ & $23.79 \pm 5.42$ & $23.75 \pm 5.41$ & $25.64 \pm 6.06$ \\
Tablet hardness $\left(\mathrm{kg} / \mathrm{cm}^{2}\right)$ & $5.70 \pm 1.77$ & $4.32 \pm 1.28$ & $6.42 \pm 4.56$ \\
Friability / hardness of tablets $(\%)$ & $0.43 \pm 0.51$ & $0.47 \pm 0.38$ & $0.32 \pm 0.31$ \\
Uniformity of tablet weight $(\mathrm{g})$ & $2.50 \pm 0.17$ & $2.53 \pm 0.13$ & $2.38 \pm 0.20$ \\
Uniformity of tablet thickness $(\mathrm{mm})$ & $4.74 \pm 1.63$ & $4.84 \pm 1.6$ & $4.16 \pm 1.09$ \\
Uniformity of tablet diameter $(\mathrm{mm})$ & $26.16 \pm 0.11$ & $26.17 \pm 0.06$ & $26.18 \pm 0.17$ \\
Tablet dissolving time (min) & $7.61 \pm 0.43$ & $7.83 \pm 0.61$ & $7.58 \pm 0.35$ \\
\hline
\end{tabular}

\section{General appearance visual}

The resulting effervescent tablets are smooth but not shiny, flat and smooth and the color is yellow.

\section{Weight uniformity}

The factors that affect the uniformity of weight are the number of grams of filling at the press site, the die used and the mass flow properties of the tablets. The weight values of the egg white effervescent tablets ranged from 2.38 to 2.53 grams with an average value of 2.47 grams. The results of the analysis of variance showed that the differe. nce in the formula for egg white effervescent tablets had no effect on the uniformity of tablet weight $(\mathrm{P}>0.05)$. Based on the criteria of the Indonesian Ministry of Health (1995), the weight uniformity of effervescent tablets is in accordance with the applicable standards.

The variations in the resulting tablet weight can be caused by the incorrect size and size distribution of the granules and poor flow, which causes the amount of mass of tablets that enter the mold to vary. Granule size that is larger than the optimal size for the mold used will affect the variation in the size of the cavity between the granules when filling the die. The resulting granule size is 11 mesh (Anwar, 2010). The weight uniformity that is usually used is a range of $\pm 3-5 \%$, with a standard of $\pm 3 \%(2,425-2,575$ grams) (According to the Indonesian Ministry of Health, 1995).

\section{Tablet Hardness}

The hardness average value of the egg white effervescent tablets was $5.48 \mathrm{~kg} / \mathrm{cm} 2$ or kP. According to the Indonesian Ministry of Health (1995), a good hardness of effervescent tablets ranges from 4-8 kP. The results of the analysis of variance showed that the different formulations had no effect on the hardness of the tablets $(\mathrm{P}>0.05)$. This is due to the difference in the concentration of effervescent mix and the concentration of lactose which have almost the same particle size and the presence of the right compressive force causes the resulting tablets to have the same hardness.

The tablet hardness of the three formulas meets the tablet hardness requirements according to the Indonesian Ministry of Health (1995). The results of research by Barzegar et. al., (2018) showed that the increased formulation of effervescent mix significantly reduced tablet 
hardness. The value of tablet hardness is also influenced by the compressive force, the higher the compressive force, the higher the resulting hardness value. One of the factors that can affect the value of tablet hardness is the hygroscopicity factor, or the ability of a substance to absorb water molecules from the environment (Nariswara et. Al., 2013; Nagashima et. Al., 2013). According to Khumaida et. al., (2017) the ideal tablet hardness is $4-10 \mathrm{~kg}$. The three formulations made show the tablet hardness value in this range and fall into the ideal category.

\section{Friability of tablet firmness}

Firmness friability of tablets is the ability of tablets to remain compact, not into powder. This quality criterion is one of the categories for assessing the ability of tablet binders. The binder used in this study is very good because it produces a small weight loss. Resistance to weight loss, indicating that the tablet is able to withstand minor scratches or damage in handling, packaging and transportation (Ansel, 1989). Usually it is desirable that the value of tablet fragility is less than or equal to $1 \%$ (RI Health Department 1995; Siregar and Wikarsa, 2010). The average yield of egg white effervescent tablets hardness of the three formulas was $0.40 \%$. Based on the analysis of variance, differences in the formulation of egg white effervescent tablets did not affect the hardness of the tablets $(\mathrm{P}>0.05)$. This is because the hardness of the effervescent tablets is the same so that the friability of the resulting tablets is the same. According to Nurwaini and Wikantyasning (2011), one that affects the fragility of effervescent tablets is the hardness of the tablet, the higher the hardness, the less the fragility of the tablet.

\section{Uniformity of size}

The tablet diameter in this study has an average of $26.17 \mathrm{~mm}$. The average thickness of the tablet is $4.58 \mathrm{~mm}$. According to Lachrnan et al. (2008), tablet thickness is influenced by the amount of mass loaded into the die, the mass density of the tablets being printed and the pressure used. According to Ansel (1989), to obtain tablets of the same thickness during production and among productions for the same formula, supervision must be carried out so that the volume of the material filled and the pressure applied remains the same.

If the pressure on the machine used is constant, the resulting variation in tablet size is influenced by the flow properties of the tablet material so that the amount of tablet mass volume must be controlled to a difference of $5 \%$. The results of the analysis of variance showed that differences in the formulation of egg white effervescent tablets had no effect on the uniformity of tablet thickness and tablet diameter (P> 0.05). These results indicate that the production process factor is uniform so that the uniformity of thickness and diameter of tablets does not differ among treatments.

\section{Time dissolve tablets}

The dissolving time of the tablets in this study was $7.67 \mathrm{~min}$. The solubility obtained was far above the standard dissolution time set by Liebeman et. al., (1989), namely the dissolving time of effervescent tablets 1 or $2 \mathrm{~min}$. Based on Harahap et. al., (2017) that the difference in the concentration of effervescent mix can reduce the solubility time. This is because the carbon dioxide compound in the effervescent mix concentration from sodium bicarbonate accelerates the effervescent dissolving time of the mangosteen rind when reacted with water.

This very long difference in dissolving time is due to the RH of the room used during the manufacturing process not in accordance with the set standards, namely $25 \% \mathrm{RH}$ and at room temperature. Effervescent tablets that are at high RH conditions will cause the tablets to easily absorb water vapor and cause acids and bases (citric acid; tartric acid and sodium bicarbonate) to react more easily to produce $\mathrm{CO} 2$ so that when dissolved their carbon power is reduced and the dissolution time becomes very long. 


\section{Chemical characteristics of egg white effervescent tablets}

Based on the results of the analysis of variance, the treatment of different concentrations of effervescent mix had a significant effect $(\mathrm{P}<0.05)$ on the aw value but did not have a significant effect $(\mathrm{P}>$
0.05 ) on the $\mathrm{pH}$ value, protein content and mineral $\mathrm{Na}$ content. The results of nonparametric Friedman analysis on water and ash content also showed no significant effect (P> 0.05). The average chemical characteristics of egg white effervescent tablets are presented in Table 4.

Table 4. Average values of chemical characteristics of egg white effervescent tablets

\begin{tabular}{|c|c|c|c|}
\hline \multirow[t]{2}{*}{ Observed Variables } & \multicolumn{3}{|l|}{ Formula } \\
\hline & 1 & 2 & 3 \\
\hline Aw & $0.58 \pm 0.04^{\mathrm{a}}$ & $0.51 \pm 0.01^{b}$ & $0.50 \pm 0.02^{b}$ \\
\hline $\mathrm{pH}$ & $5.27 \pm 0.37$ & $5.56 \pm 0.66$ & $5.31 \pm .60$ \\
\hline Water content $(\%)$ & $5.24 \pm 0.11$ & $5.22 \pm 1.52$ & $5.54 \pm 1.75$ \\
\hline Ash content (\%) & $17.18 \pm 0.36$ & $18.32 \pm 0.85$ & $22.79 \pm 3.72$ \\
\hline Protein content (\%) & $8.42 \pm 0.84$ & $8.15 \pm 0.44$ & $8.07 \pm 0.20$ \\
\hline Na content $(\%)$ & $5.57 \pm 1.98$ & $9.05 \pm 1.23$ & $8.33 \pm 3.54$ \\
\hline
\end{tabular}

Notes : Different superscripts on the same line show significant differences $(\mathrm{P}<0.05)$

\section{Water activities (Aw)}

The need for water for the growth of microorganisms is known as aw (water activity). The results of the variance analysis showed that the formulation had a significant effect $(\mathrm{p}<0.05)$ on the aw value. Formulation 1 is higher than the other formulations. This is because the effervescent mix concentration of $55 \%$ (formulation 1) contains more fillers (lactose) compared to the effervescent mix concentrations of $60 \%$ (formulation 2) and $65 \%$ (formulsia 3 ) so that aw in formulation 1 is also high. The aw values obtained were below the minimum value for growing microorganisms $(<0.6)$. This aw value will increase if the storage technology is not appropriate.

\section{pH value}

$\mathrm{pH}$ is an important factor in determining the durability of food products. Food with a $\mathrm{pH}>4.5$ and a $\mathrm{pH}<0.85$ is included in the moderate risk category. The $\mathrm{pH}$ of effervescent tablets in this study has an average $\mathrm{pH}$ value of 5.38. The results of the analysis of variance showed that the formulation treatment did not affect the $\mathrm{pH}$ value $(\mathrm{pH}>0.05)$. This is due to the addition of tartric acid and citric acid to the three formulations in a range that is not much different, namely $28.42 \%$ to $33.58 \%$. Based on research by Mutiarahma et. al., (2019) adding citric acid to the effervescent tablet formulation will reduce the $\mathrm{pH}$ of the resulting tablets. The results obtained are different from the literature. This is due to the addition of citric and tartaric acid in the preparation of effervescent tablets in the concentration range of $28.42 \%, 31 \%$ and $33.83 \%$. This range does not cause a different result in the $\mathrm{pH}$ value. The added acid caused the resulting effervescent tablets to have a $\mathrm{pH}$ of 5.27 to 5.56 .

\section{Water content}

The water content value of egg white effervescent tablets obtained in this study was 5.33. This value is in accordance with the BPOM circular letter (2015), namely the water content requirement for effervesent tablet preparations in health supplements is less than $10 \%$. Based on the results of nonparametric Friedman analysis, this showed that the treatment of different concentrations of effervescent mix had no significant effect $(\mathrm{P}>0.05)$ on the water content of egg white effervescent tablets. The resulting moisture content is still above $5 \%$, the value required by Lieberman et al., (1989). According to Pribadi et. al., (2014) the materials used for the tablet-making process are very easy to 
absorb moisture from the air so that the room has a maximum $\mathrm{Rh}$ of $25 \%$ and a maximum temperature of $25^{\circ} \mathrm{C}$ which is required in the manufacture of these tablets. Based on research by Mutiarahma et. al., (2019) the addition of citric acid to the effervescent tablet formulation will increase the water content of the resulting tablets. This is because citric acid is hygroscopic and readily absorbs water.

\section{Ash content}

The ash content contained in egg white effervescent tablets comes from citric acid, tartric acid and sodium bicarbonate. The mean value of ash content $(\%)$ of egg white effervescent tablets was $19.43 \%$. The results of non-parametric analysis by Friedman showed that the different treatment concentrations of the effervescent mix used had no significant effect $(\mathrm{P}>0.05)$ on the ash content of the resulted egg white effervescent tablets.

Based on research by Harahap et al. (2017) increasing the effervescent mix formulation increased the value of the ash content. Research conducted is different from the literature because the concentrations studied are different. The concentrations of the efffervescent mix studied in this study were $55 \%, 60 \%$ and $65 \%$. A $5-10 \%$ difference does not cause a change in ash content.

\section{Protein Content}

The protein source in this egg white effervescent tablet is obtained from egg white powder. The average protein content (\%) of egg white effervescent tablets ranged from 8.07 to 8.42 . The results of the analysis of variance showed that the concentration of effervescent mix used had no effect on the protein content of egg white effervescent tablets $(\mathrm{P}>0.05)$. The target consumption of animal protein for the Indonesian population of $6 \mathrm{~g} /$ capita/day is still far from expectations. These egg white effervescent tablets contain animal protein for formulas 1,2 and 3 respectively which are 8.42, 8.15 and $8.07 \%$ and there are equivalent to 0.21 ,
0.20 and $0.20 \mathrm{~g} /$ tablet so that by consuming 1 egg white effervescent tablet can provide protein intake animal about $3.5 \%$ of the target consumption of animal protein in Indonesia in a day (Rusfidra, 2005). Egg white effervescent tablets can be an additional source of protein without reducing the consumption of other sources of animal protein such as: milk, meat and fish.

\section{Mineral Na levels}

The reaction of the effervescent itself between acids and bases will produce salts where there is the mineral $\mathrm{Na}$ in it (Lieberman et al., 1989). The values of mineral $\mathrm{Na}$ content (\%) of egg white effervescent tablets were $5.57 \pm 1.98$ (formula 1), $9.05 \pm 1.23$ (formula 2) and $8.33 \pm 3.54$ (formula 3 ) (Table 4). ). The results of the analysis of variety showed that the concentration of the effervescent mix used had no significant effect $(\mathrm{P}>0.05)$ on the $\mathrm{Na}$ mineral content of egg white effervescent tablets.

\section{Organoleptic Characteristics of Egg white Effervescent Tablets}

The average result of the tablet form hedonic test is 4.81 or close to the value of 5 , meaning that the panelists like the shape of this egg white effervescent tablet. The results of the analysis of variance showed that the different formulations did not affect the panelists' preference for the tablet shape (P> 0.05). This is because all formulations produce egg white effervescent tablets that are thin, round and yellow in color.

\section{Aroma}

The average value of the hedonic test results on the aroma of egg white effervescent tablets was 4.49 , meaning that the panelists liked the aroma produced by this egg white effervescent tablet. The results of the analysis of variance showed that the concentration of the effervescent mix treatment used did not affect the panelists' preference for the aroma of tablets $(\mathrm{P}>0.05)$. This is because the lemon flavor 
is added to the tablet, so that the fishy aroma produced from the egg white can be covered and accepted by the panelists.

\section{Dissolving Time}

The dissolving time of the tablet is the main requirement that effervescent tablets must have. This is because generally in the market, it really emphasizes the dissolving ime of the product. The average value of the panelists' preference for the dissolving time of the egg white effervescent tablets was 3.41, which means they did not like it. The results of the analysis of variance showed that the differences in the concentration of effervescent mix did not affect the panelists' preference for the dissolving time of the tablets ( $P>0.05)$. The three formulations produced tablets with almost the same dissolving time and quite a long time (+7.67 $\mathrm{min})$, so they were not liked by the panelists.

Table 5. The hedonic test average value of egg white effervescent tablets

\begin{tabular}{lcccc}
\hline \multirow{2}{*}{ Assessment Criteria } & \multicolumn{4}{c}{ Formulation } \\
\cline { 2 - 5 } & F1 & F2 & F3 & Average \\
\hline Tablet shape & $4.80 \pm 0.69$ & $4.82 \pm 0.62$ & $4.80 \pm 0.60$ & 4.81 \\
Aroma & $4.18 \pm 1.21$ & $4.74 \pm 1.23$ & $4.56 \pm 1.39$ & 4.49 \\
Dissolving time & $3.34 \pm 1.10$ & $3.46 \pm 1.26$ & $3.42 \pm 1.42$ & 3.41 \\
Color & $4.34 \pm 0.77$ & $4.58 \pm 0.83$ & $4.66 \pm 0.85$ & 4.53 \\
Taste & $4.10 \pm 1.07$ & $4.06 \pm 1.00$ & $4.18 \pm 1.04$ & 4.11 \\
Overall Assessment & $4.14 \pm 0.95$ & $4.14 \pm 0.90$ & $4.36 \pm 0.94$ & 4.21 \\
\hline
\end{tabular}

Notes : (1) extremely disklike, (2) really dislike, (3) dislike, (4) quite like, (5) like, (6) really like and (7) extremely like

\section{Color}

The average result of the hedonic test conducted by the panelists on the color of the egg white effervescent tablet was 4.53 , meaning that the panelists liked the color of this egg white effervescent tablet product. The results of the analysis of variance showed that the different treatment of different effervescent mix concentrations had no effect on the preference of the panelists on the color of the egg white effervescent tablets ( $\mathrm{P}>0.05)$. This is because the colors produced are all the same, namely yellow.

\section{Taste}

Taste is a determining factor for consumer acceptance of food products. The results of the hedonic test conducted gave the average value of the panelists' preference for the taste of egg white effervescent drinks, namely 4.11 , which means they like it a little.

The results of the analysis of variety showed that the treatment with different concentrations of effervescent mix did not affect the taste preferences of egg white effervescent drinks $(\mathrm{P}>0.05)$.

\section{Overall Assessment}

The overall assessment was obtained after the panelists thoroughly assessed the shape, aroma, dissolving time and taste caused by the egg white effervescent tablets. This assessment is a form of panelist acceptance of this new product. The result of panelists' preference for the overall assessment of egg white effervescent tablets was 4.21. This means that the panelists rather like egg white effervescent tablet products. Based on the results of analysis of variance, the difference in the concentration of effervescent mix did not affect the overall assessment of egg white effervescent tablets $(\mathrm{P}>0.05)$.

\section{CONCLUSIONS}

The physical characteristics of the effervescent tablets with the addition of egg white powder and the difference in the concentration of effervescent mix as 
treatments were not significantly different among treatments. The results showed that almost all of the egg white effervescent tablets were in accordance with the standards of the Ministry of Health of the Republic of Indonesia, namely compressibility of granules, uniformity of tablet weight, tablet hardness, tablet friability, uniformity of thickness and uniformity of diameter $(26.17 \mathrm{~mm})$, but dissolving time $(7.67 \mathrm{~min})$ which was far from standard effervescent tablets. Chemical characteristics of egg white effervescent tablets did not change with the treatment of effervescent mix concentrations of 55,60 and $65 \%$ but the water activity (aw) of the effervescent tablets changed. Increasing the concentration of effervescent mix treatment can reduce the aw value from 0.58 to 0.50 . The organoleptic test results on the overall assessment of egg white effervescent tablets were somewhat favorable.

\section{ACKNOWLEDGEMENTS}

Authors would like to thank Directorate of Higher Education, Ministry of Culture and education Republic of Indonesia for the research fund.

\section{REFERENCES}

American Pharmaceutical Association. (1994). Handbook of Pharm Mexcipient (2nd ed.).

Ansel, H. C. (1989). Pengantar Bentuk Sediaan Farmasi (F. Ibrahim (ed.); 4th ed.). Universitas Indonesia Press.

Anwar, K. (2010). Formulasi sediaan tablet effervescent dari ekstrak kunyit (Curcuma domestica Val.) dengan variasi jumlah asam sitrat-asam tartrat sebagai sumber asam. Sains Dan Terapan Kimia, 4(2), 168-178.

Apriyantono, Fardiaz, A., Puspitasari, N. L., Sedarnawati, \& Budiyanto, S. (1989). Petunjuk Laboratorium Analisis Pangan. Pusat Antar Universitas Pangan dan Gizi, IPB.
Asoodeh, A., Memarpoor Yazdi, M., \& Chamani, J. (2012). Purification and characterisation of angiotensin I converting enzyme inhibitory peptides from lysozyme hydrolysates. Food Chemistry, 131(1), 291-295. https:// doi.org/10.1016/j.foodchem.2011.08. 039

Aulton, M. (2002). Pharmaceutics: The Science Of Dosage Form Design (Second Edition). In Edinburgh: Churchill Livingstone (2nd ed.). Churcil Livingstone.

Barzegar, Z., Jahadi, M., \& Hanifpour, M. A. (2018). Physical properties of fermented milk tablets. Journal of Food Biosciences and Technology Science and Research Branch, 8(1), 291-295.

Gunawan-Puteri, M. D. P. T., Rustandi, F., \& Hendra, P. (2018). Spray dried aqueous extract of lemongrass (Cymbopogon citratus) exhibits in vitro and in vivo anti hyperglycemic activities. Journal of Pharmaceutical Sciences and Community, 15(2), 55-61. https://doi.org/10.24071/jpsc.1521531

Harahap, R. A., Efendi, R., \& Ayu, D. F. (2017). Konsentrasi effervecscent mix dalam pembuatan serbuk effervescent ekstrak kulit buah manggis (Garcinia mangostana L.). Jom FAPERTA UR, 4(1), 1-14.

Khumaida, A., Mulyawati, D., Irawati, I., Prawati, N., \& Amrillah, F. (2017). Formulasi tablet effervescent berbahan baku ekstrak kulit buah rambutan (Nephelium lappaceum) SEBAGAI antioksidan. Indonesian Journal of Pharmaceutical Science and Technology, 6(1).

Lachman, L., Lieberman, H. A., \& Kaning, J. L. (2008). Teori dan Praktek Farmasi Industri Edisi III. In Universitas Indonesia, Jakarta. Marcel Dekker Inc.

Lieberman, H. A., Lachman, L., \& Schwartz, J. B. (1989). Teori dan Praktek Farmasi Industri (S. Suyatmi (ed.)). Universitas Indonesia Press. 
Mutiarahma, S., Pramono, Y. B., \& Nurwantoro. (2019). Evaluasi kadar gula, kadar air, kadar asam dan $\mathrm{pH}$ pada pembuatan tablet effervescent buah nangka. Jurnal Teknologi Pangan, 3(1), 36-41.

Nagashima, A. I., Pansiera, P. E., Baracat, M. M., \& Gómez, R. J. H. C. (2013). Development of effervescent products, in powder and tablet form, supplemented with probiotics Lactobacillus acidophilus and Saccharomyces boulardii. Food Science and Technology, 33(4), 605611. https://doi.org/10.1590/S010120612013000400002

Nariswara, Y., Hidayat, N., \& Effendi, M. (2013). Pengaruh waktu dan gaya tekan terhadap kekerasan dan waktu larut tablet effervescent dari serbuk wortel (Daucus Carota L.). Jurnal Industria, 2(1), 27-35.

Nimalaratne, C., \& Wu, J. (2015). Hen egg as an antioxidant food commodity: a review. Nutrients, 7(10), 8274-8293. https://doi.org/10.3390/nu7105394

Nurwaini, S., \& Wikantyasning, E. (2011). Formulasi tablet hisap ekstrak daun kemangi (Ocimum sanctum L): pengaruh karboksimetil selulosa sebagai bahan pengikat terhadap sifat fisik tablet. Jurnal Penelitian Sains Dan Teknologi, 12(1), 45-57.
Pribadi, Y. S., Sukatiningsih, \& Sari, P. (2014). Formulasi tablet effervescent berbahan baku kulit buah naga merah (Hylocereus polyrhizus) dan buah salam (Syzygium polyanthum [Wight.] Walp). Berkala Ilmiah Pertanian, 1(4), 86-89.

Siregar, C., \& Wikarsa, S. (2010). Teknologi Farmasi Sediaan Tablet. In DasarDasar Praktek. Kedokteran EGC.

Stadelman, W. J., \& Cotterill, O. J. (1995). Egg Science and Technology (4th ed.). Food Product Press. An Imprint of The Haworth Press, Inc.

Steel. R. G, \& Torrie, J. H. (1995). Prinsip dan Prosedur Statistik (B. Sumantri (ed.)). PT Gramedia Pustaka Utama.

Syah, D., Utama, S., Mahrus, Z., Fauzan, F., Siahaan, R., Oktavia, O., Supriyadi, S., \& Kartawijaya, W. (2005). Manfaat dan Bahaya Bahan Tambahan Pangan. Himpunan Alumni Fakultas Teknologi Pertanian. Wulandari, Z., Fardiaz, D., Thenawidjaja, M., Yuliana, N. D., \& Budiman, C. (2020). Purification and sweetness properties of egg white lysozymes from Indonesian local poultry of ayam kampung and Cihateup duck. Journal of Food Measurement and Characterization, 14(1), 366-377. https://doi.org/10.10 07/s11694-019-00299-x 